\title{
SISTEM PENGOLAHAN DATA PERILAKU SISWA DENGAN PENERAPAN KUM DI SMAN 2 DUMAI BERBASIS WEB
}

\author{
Suci Habisal ${ }^{1}$, Antony Sinaga ${ }^{2}$, Ade Saputra ${ }^{3}$ \\ ${ }^{1,2,3}$ Sekolah Tinggi Managemen Informatika dan Komputer (STMIK) Dumai \\ Jl.Utama Karya Bukit Batrem II Dumai-Riau kode pos 28811 \\ e-mail :sucihabisal251018@gmail.com
}

\begin{abstract}
ABSTRAK
Kum adalah salah satu bentuk aturan yang ditetapkan disetiap sekolah bersifat mengikat dengan memiliki point masing-masing sesuai kesalahan yang ada, dengan tujuan untuk dilaksanakan terhadap peraturan tersebut. Kum saat ini maih dicatat manual, sistem manual yang belum terkomputerisasi sehingga dikhawatirkan akan terjadi manipulasi data oleh siswanya sendiri dan memanipulasi tentang buku kum ke orang tua dari siswa tersebut. Dengan permasalahan tersebut di atas perlu dibuat sebuah sistem pengolahan data kum perilaku yg berbasis web agar dapat mempermudah guru dalam mengolah data kesalahan siswa setiap hari serta tidak ada manipulasi data oleh siswa kepada orang tua mereka. Sehingga orang tua dan guru dapat melihat data siswa setiap hari secara online dan pengolahan data menjadi lebih efektif dan efisien.
\end{abstract}

Kata kunci : Kum, Perilaku, Siswa, Web, PHP

\section{PENDAHULUAN}

Sekolah Menengah Atas Negeri 2 Dumai (SMA Negeri 2 Dumai) atau sering disingkat smanda adalah salah satu sekolah menengah atas yang cukup diminati dikalangan masyarakat. Dalam menjalankan fungsinya sebagai lembaga pendidikan, SMA Negeri 2 Dumai dibagi atas dua (3) jurusan. Yaitu jurusan Ilmu Matematika IPA (MIPA), Ilmu Pengetahuan Sosial (IPS), dan Ilmu Bahasa (IBB). SMA Negeri 2 Dumai berdiri sejak tahun 1979, salah satu SMA Negeri yang terlama di Dumai. Kemajuan ilmu pengetahuan dan teknologi pada kebutuhan manusia semakin kompleks. Sehingga manusia selalu termotivasi untuk menemukan inovasi terbaru dalam mempermudahkan memecahkan solusi masalah dalam pekerjaanya. Komputer adalah salah satu inovasi manusia untuk membantu dalam mengatasi kesulitan dibidang data untuk pemecahan masalah, agar dapat terselesaikan masalah dengan cepat, tepat, dan akurat.

Kum adalah salah satu bentuk aturan yang ditetapkan disetiap sekolah bersifat mengikat dengan memiliki point-point masingmasing sesuai kesalahan yang ada. Dengan tujuan untuk dilaksanakan terhadap peraturanperaturan yang ada disekolah. Kum sangat bagus diberlakukan karena untuk menjaga disiplin anak-anak disekolah.

SMA Negeri 2 merupakan salah satu sekolah SMA favorit di Dumai dan memiliki siswa yang terbanyak dari seluruh SMA yang ada. Setiap hari siswa hampir semua yang berbuat kesalahan, akan tetapi sistem masih menggunakan sistem manual yang belum terkomputerisasi sehingga dikhawatirkan akan terjadi manipulasi data oleh siswanya sendiri dan memanipulasi tentang buku kum ke orang tua dari siswa tersebut. Buku kum yang masih manual ini juga sulit di cari dan membutuhkan waktu yang lama karena berada di berbagai tempat. Buku kum bila ditangan siswa juga mudah rusak dan hilang.

\section{a. Pengertian Sistem Informasi}

Sistem adalah suatu kesatuan yang terdiri komponen atau elemen yang dihubungkan untuk memudahkan aliran informasi, materi, atau energi, untuk mencapai suatu tujuan. (Kaharu \& Sakina, 2015)

Informasi adalah data yang telah diolah sehingga lebih berarti dan berguna bagi penerima. Jadi, sumber dari informasi adalah data. Informasi juga sekumpulan fakta (data) telah yang diorganisasikan dengan cara tertentu 
IN F O R M A I I A

Jurnal Informatika, Manajemen dan Komputer, Vol. 10 No. 1, MEl 2018

eISSN : 2580-3042

pISSN : 1979-0694

sehingga memiliki arti bagi penerima. (Kaharu \& Sakina, 2015)

Jadi, Sistem Informasi adalah kumpulan elemen yang saling berhubungan satu sama lain yang membentuk satu kesatuan untuk mengintegrasikan data, memproses dan menyimpan serta mendistribusikan informasi. (Rohayati \& HJ, 2016)

\section{b. Pengertian Basis Data}

Basis data (database) sebagai "suatu kumpulan data terhubung (interrelated data) yang disimpan secara bersama-sama pada suatu media", tanpa suatu kerangkapan data (kalaupun ada maka kerangkapan data tersebut harus seminimal mungkin dan terkontrol (controlled redudncy), data disimpan dengan cara-cara tertentu, sehingga mudah untuk digunakan atau ditampilkan kembali, dapat digunakan oleh satu atau lebih program apliksi secara optimal. (Drs. Hermansyah Sembiring \& Nurhayati, S.Kom., 2012)

\section{c. Pengertian World Wide Web}

World Wide Web (WWW), lebih dikenal dengan web, merupakan salah satu layanan yang didapat oleh pemakai komputer yang terhubung ke internet (Sidik \& Pohan, 2010) didalam jurnalnya Faizal Ari Prabowo dan Mamay Syani.(Ari Prabowo \& Syani, 2017)

\section{d. Pengertian Bootstrap}

Bootstrap merupakan sebuah framework yang dapat menyelesaikan permasalahan dalam mendesain web. Slogan dari framework ini adalah "Sleek, intuitive, and powerful front-end framework for faster and easier web development", yang berarti kita dapat mendesain sebuah website dengan lebih rapi, cepat dan mudah. (Zakir, 2016)

\section{e. MySQL}

MySQL adalah database server relational yang gratis dibawah lisensi GNU General Public Licence. Dengan sifatnya yang open source, memungkinkan juga user untuk melakukan modifikasi pada souce code-nya untuk memenuhi kebutuhan spesifik mereka sendiri. MySQL merupakan database server multi-user dan multi- threaded yang tangguh (rebust). Dengan memiliki banyak feature MySQL bisa bersaing dengan database komersial sekalipun. MySQL menjadi database pilihan untuk banyak pengguna PHP. (Nurfajrina, Suryatiningsih;, \& Siswanto, 2016)

\section{f. PHP}

Kepanjangan PHP adalah Personal Home Page (Situs personal), merupakan bahasa pemrograman web yang bersifat server side (bekerja di sisi server). PHP merupakan script yang menyatu dengan Hyper Text Markup Language (HTML) dan berada pada server (server side HTML embedded scripting). Sebagian besar sintaks mirip dengan Bahasa C, Java, Asp, dan Perl, ditambah beberapa fungsi PHP yang spesifik. Tujuan utama Bahasa ini adalah untuk memungkinkan perancangan web untuk menulis halaman web dinamik dengan cepat. Kelebihan dari bahasa pemrograman ini adalah seluruh aplikasi berbasis web dapat dibuat dengan PHP. Namun kekuatan yang paling utama PHP adalah pada konektivitasnya dengan sistem database.(Nurfajrina et al., 2016)

\section{g. HTML}

HTML (Hyper Text Markup Language) merupakan bahasa asli dari www, yang telah menjadi bahasa standar untuk menampilkan data di internet. (Web \& Kusuma, 2015)

\section{h. Sistem Informasi Berbasis Web}

Sistem Informasi Berbasis Web adalah seperangkat komponen yang saling berhubungan yang berfungsi mengumpulkan, memproses, menyimpan, dan mendistribusikan informasi untuk mendukung pembuatan keputusan dan pengawasan dalam organisasi. (Dahle \& Holman, 1961)

\section{i. ERD}

Sebuah Entity Relaltionship Diagram (ERD) merupakan sebuah gambaran yang menunjukkan informasi yang telah dibuat, disimpan dan digunakan oleh suatu sistem bisnis. Ada tiga elemen dasar dalam ERD (entitas, atribut dan hubungan), yang masingmasing diwakili oleh simbol grafis yang berbeda. (Yusuf, Kusniyati, \& Nuramelia, 2016)

\section{j. Basis Data}

Basis data terdiri dari 2 kata yaitu Basis dan Data, basis dapat diartikan sebagai markas atau gudang, tempat bersarang/berkumpul dan data adalah representasi fakta dunia nyata yang mewakili suatu objek yang direkam dalam bentuk angka, huruf, simbol, teks, gambar atau kombinasinya. (Nia, Kumaladewi, Meinarini Catur Utami, Iskandar, 2015) 
I N F O R M A I I A

Jurnal Informatika, Manajemen dan Komputer, Vol. 10 No. 1, MEl 2018

eISSN : 2580-3042

pISSN : 1979-0694

\section{METODE PENELITIAN}

Untuk membantu dalam penyusunan metode penelitian ini, maka perlu adanya susunan kerangka kerja yang jelas tahapan-tahapannya. Kerangka kerja ini merupakan langkah-langkah yang akan dilakukan dalam penyelesaian masalah yang ada di SMA Negeri 2 Dumai, berikut adalah kerangka kerja:

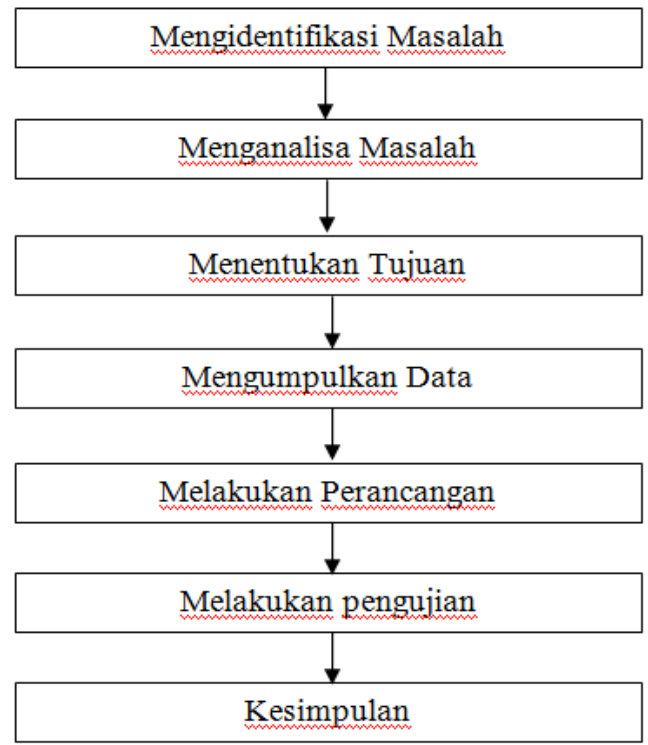

Gambar 1. Kerangka Kerja

Berdasarkan gambar diatas dapat dijelaskan urutan-urutan langkah kerja sebagai berikut:

1. Mengidentifikasi Masalah

Permasalahan utama dalam penelitian ini ialah buku KUM yang masih manual sehingga data dimanipulasi oleh siswa.

2. Menganalisa masalah

Penganalisaan terhadap masalah yang telah diindentifikasi perlu dilakukan, apakah data mengenai buku KUM perilaku sisa SMA Negeri 2 Dumai dapat dianalisa dan ditambah dengan sistem pengolahan data perilaku siswa dengan penerapan KUM di SMAN 2 Dumai berbasis web. Dengan tujuan untuk mempermudah pencarian data perilaku siswa serta tidak ada manipulasi siswa nya sendiri.

3. Menentukan Tujuan

Tujuan utama dalam penelitian ini adalah untuk menyediakan informasi kepada orang tua siswa tentang perilaku anaknya setiap hari disekolah, serta tidak ada manipulasi siswa dan pencarian data perilaku siswa yang lebih cepat.
4. Mengumpulkan data

Pengumpulan data mengenai data KUM diperoleh dengan cara melakukan pengamatan langsung ke SMA Negeri 2 Dumai.

5. Melakukan Perancangan

Adapun penjelasan lebih rinci mengenai perancangan sistem pengolahan data perilaku siswa dengan penerapan kum di SMAN 2 Dumai berbasis web digambarkan dengan menggunakan DFD.

6. Melakukan Pengujian

Melakukan pengujian merupakan proses terakhir sebelum mendapatkan pengetahuan baru dari data yang ada. Pada tahap ini, hasil penerapan program Kum menggunakan software notepad ++ akan dilakukan pengujian kembali, dengan tujuan untuk mendapatkan hasil yang maksimal dari data yang ada.

7. Kesimpulan

Setelah dilakukan pengujian, langkah berikutnya adalah penentuan atau pengambilan keputusan berdasarkan hasil yang telah dilakukan sebelumnya, sehingga akan muncul hasil program yang prioritas atau yang tidak prioritas.

\section{HASIL DAN PEMBAHASAN}

a. Analisa Sistem Sedang Berjalan (ASI)

Aliran sistem informasi yang sedang berjalan pada sistem pengolahan data perilaku siswa dengan penerapan KUM di SMA Negeri 2 dumai dapat dilihat pada gambar di bawah ini:

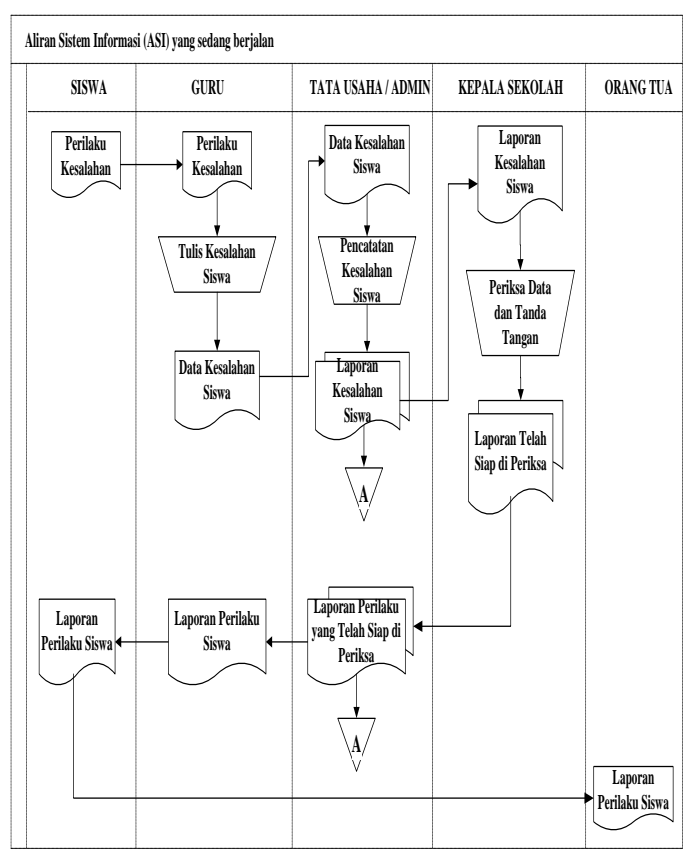

Gambar 2. ASI Lama 
I N F O R M A I I A

Jurnal Informatika, Manajemen dan Komputer, Vol. 10 No. 1, MEl 2018

eISSN : 2580-3042

pISSN : 1979-0694

Berikut adalah keterangan dari gambar 2 aliran sistem informasi yang sedang berjalan (ASI Lama) pada sistem pengolahan data perilaku siswa dengan penerapan kum di SMA Negeri 2 Dumai Berbasis Web yaitu:

1. Perbuatan yang dilakukan siswa ditulis manual terlebih dahulu oleh guru

2. Data kesalahan tersebut di proses ke ruang tata usaha

3. Tata usaha merekapitulasi kesalahan siswa tersebut dengan mencatat

4. Kemudian tata usaha mengeluarkan buku kum yang diberikan ke wali kelas/ guru yang membutukan yang telah di isi kesalahan siswa

5. Dan lihat dan di setujui/di tanda tangani oleh kepala sekolah

6. Dan guru memberi saran

7. Kemudian buku setelah selesai diberikan ke siswa

8. Siswa wajib melaporkan buku KUM kepada orang tua

\section{b. Aliran Sistem Informasi Yang Baru (ASI Baru)}

Aliran sistem informasi yang baru pada SMAN 2 DUMAI tidak jauh berbeda dengan aliran sistem informasi yang lama atau yang sedang berjalan, hanya saja pada aliran sistem informasi baru sudah menggunakan penyimpanan sistem database sehingga dalam proses pembuatan laporan dapat dilakukan dengan cepat dan akurat sehingga lebih efektif dan efisien. Dapat dilihat pada gambar 3.

Berikut adalah keterangan dari gambar 3 aliran sistem informasi yang sedang berjalan (ASI Baru) pada sistem pengolahan data perilaku siswa dengan penerapan kum di SMA Negeri 2 Dumai Berbasis Web yaitu:

1. Admin/Tata Usaha Menginput data siswa, data guru, data kelas, data wali kelas dan bagi kelas

2. Data yang diinput oleh tata usaha diproses oleh sistem dan tersimpan didalam database dan menghasilkan laporan data guru, laporan data siswa, laporan data wali kelas dan laporan bagi kelas

3. Kemudian guru BP menginput data Kum dan data proes perilaku siswa

4. Data yang di input oleh guru BP diproses oleh sistem dan tersimpan didalam database dan menghasilkan laporan Kum, laporan Kum Persiswa, laporan Kum perTahun
Ajaran, laporan Kum Perkelas, laporan kum persemester,laporan Kum PerMinimal.

5. laporan Kum, laporan Kum Persiswa, laporan Kum per Tahun Ajaran, laporan Kum Perkelas, laporan kum persemester, laporan Kum PerMinimal diberikan kepada kepala sekolah.

6. dan siswa hanya bisa melihat laporan Kum Per Siswa disistem

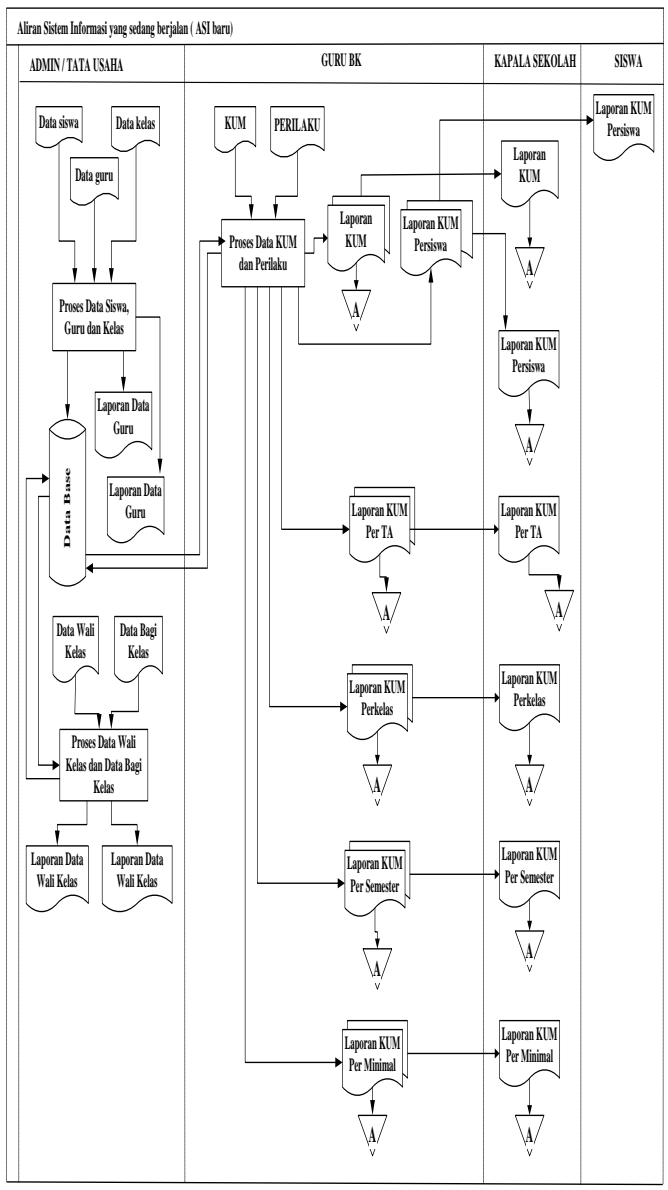

Gambar 3. ASI Baru

\section{c. Contex Diagram}

Contex Diagram merupakan level teratas (Top Level) dari diagram arus data. Contex Diagram menggambarkan hubungan input /output antara sistem dengan dunia luarnya (kesatuan luar). 
IN F ORM A I K A

Jurnal Informatika, Manajemen dan Komputer, Vol. 10 No. 1, MEl 2018

elSSN : 2580-3042

pISSN : 1979-0694

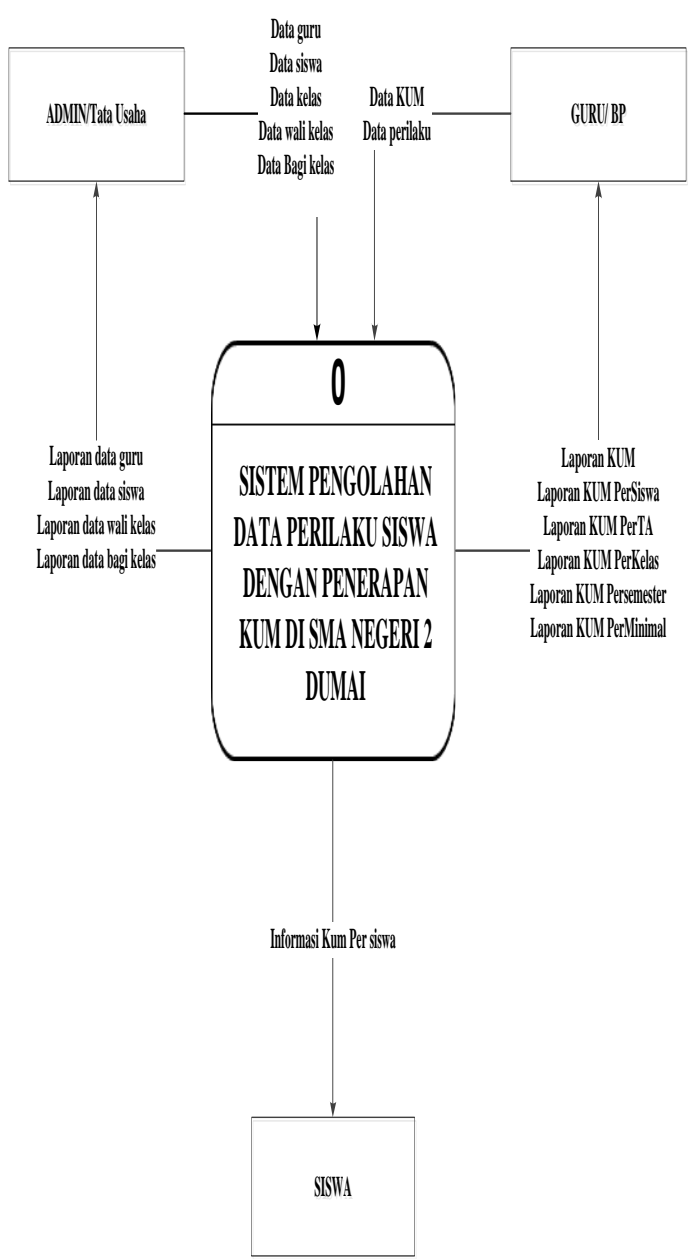

Gambar 4. Contex Diagram

\section{d. Data Flow Diagram}

Diagram aliran data merupakan alat pemodelan yang berfungsi untuk mengambarkan sistem sebagai jaringan kerja antar fungsi berhubungan satu sama lain dengan aliran desain penyimpanan data.

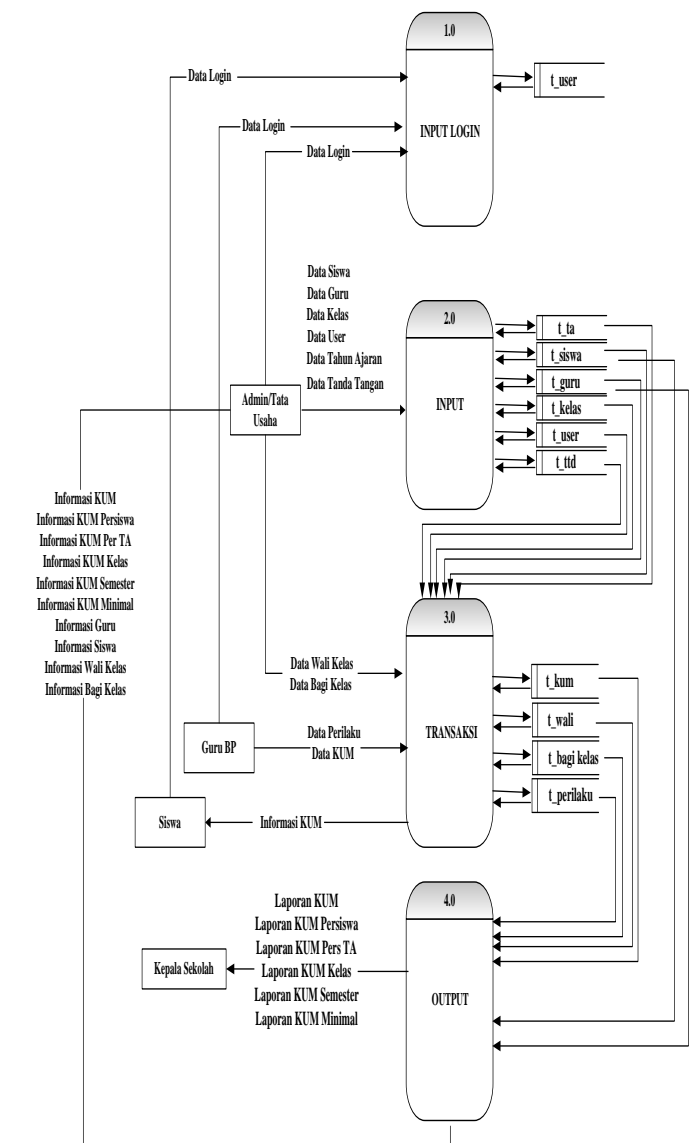

Gambar 5. Data Flow Diagram

e. Tampilan Program

1. Data Input Siswa

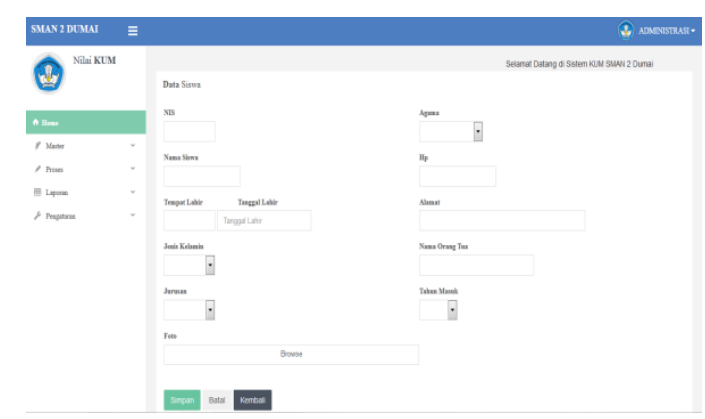

Gambar 6. Form Input Data Siswa

a. Pada form menu utama klik sub menu master.

b. Kemudian pilih siswa.

c. Kemudian isi Nis, Nama Siswa, Tempat Lahir, Tanggal Lahir, Jenis kelamin, Jurusan, Foto, Agama, Hp,Alamat, Nama Orang Tua dan Tahun Masuk.

d. Klik administrator dan klik tombol logout apabila ingin keluar dari form input data siswa. 
INFORM A I I A

Jurnal Informatika, Manajemen dan Komputer, Vol. 10 No. 1, MEl 2018

eISSN : 2580-3042

pISSN : 1979-0694

2. Data Input Guru

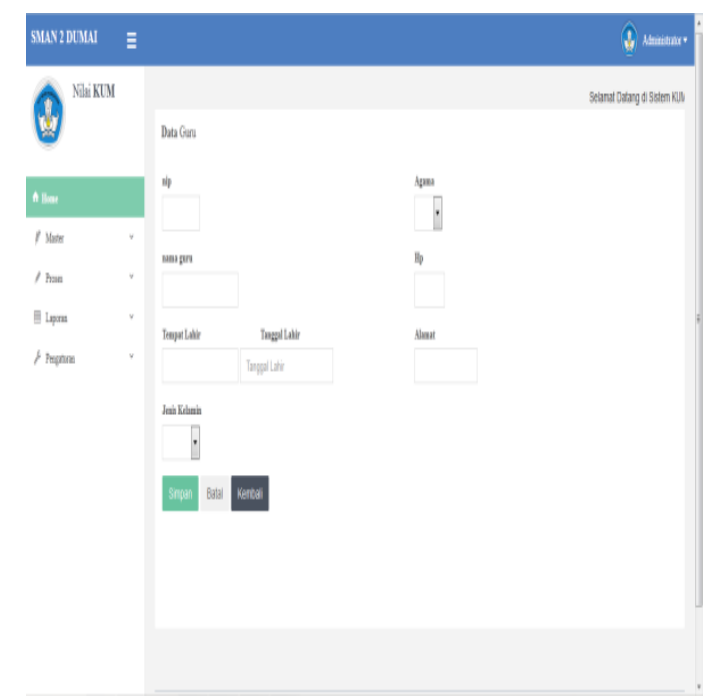

Gambar 7. Form Input Data Guru

a. Pada form menu utama pilih sub menu master, klik guru.

b. Input nip, nama guru, tempat lahir, jenis kelamin, agama, no hp dan alamat.

c. Klik administrator dan klik tombol logout apabila ingin keluar dari form input data guru.

3. Data Input Kelas

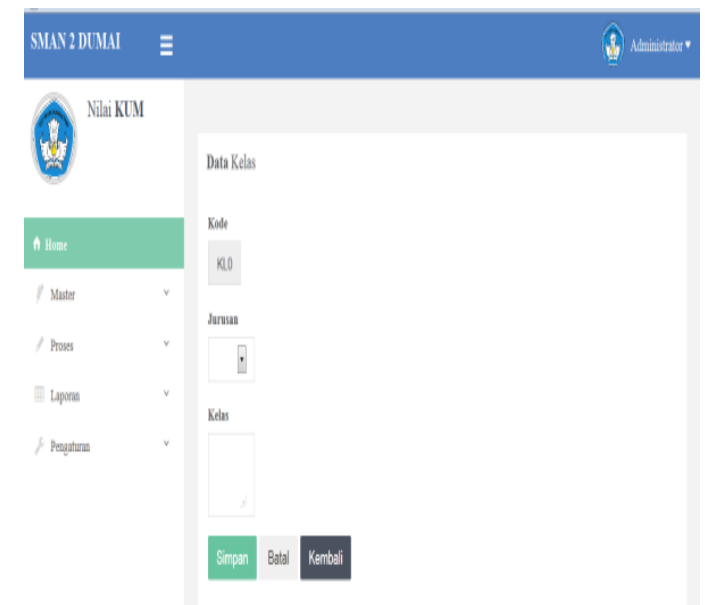

Gambar 8. Form Input Data Kelas

a. Pada form menu utama pilih sub menu master, klik kelas.

b. Input kode, jurusan dan kelas kemudian klik untuk menyimpan, maka data akan tersimpan, jika ingin kembali klik kembali dan jika batak klik tombol batal c. Klik tombol administrator dan klik logout apabila ingin keluar dari form input data kelas.

4. Data Input Data User

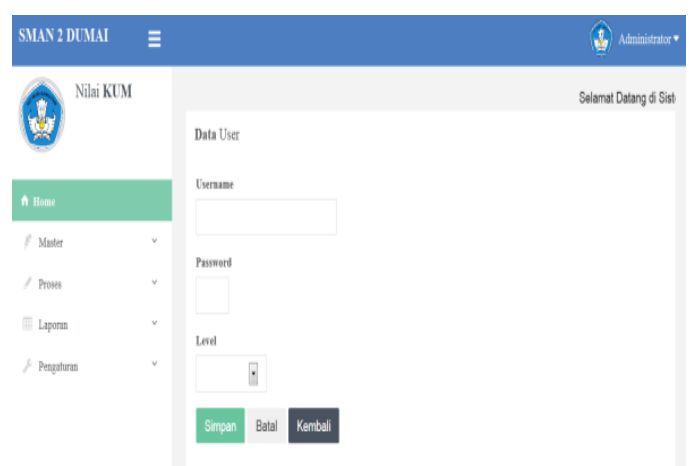

Gambar 9. Form Data User

a. Pada form menu utama pilih sub menu master pengaturan, klik user.

b. Input kode username, password dan level untuk menyimpan klik tombol simpan dan untuk kembali klik tombol kembali, apabila ingin batal klik tombol batal.

5. Data Input Tanda Tangan

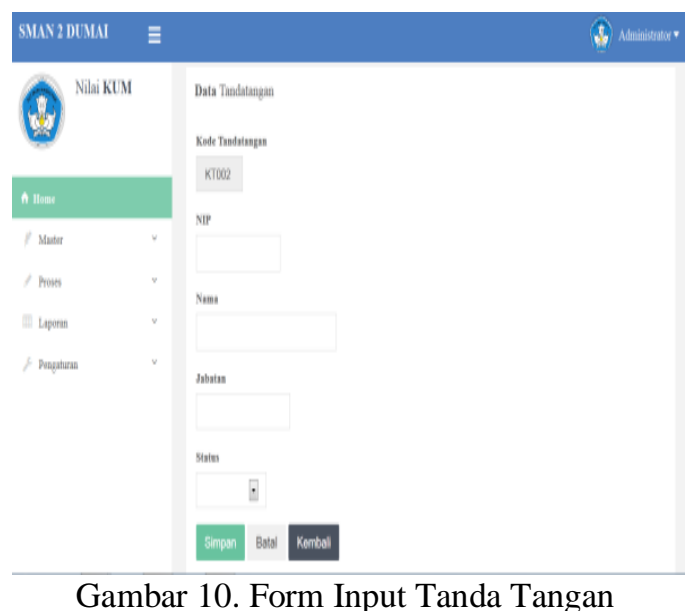

a. Pada form menu utama pilih sub menu pengturan, klik tandatangan.

b. Input kode tandatangan, NIP, nama, jabatan dan status kemudian klik tombol simpan untuk disimpan kedatabase, klik tombol kembali untuk kembali dan klik tombol batal untuk batal.

c. Klik tombol adminidtrator dan klik tombol logout apabila ingin keluar dari form input data tandatangan. 
I N F O R M A T I K A

Jurnal Informatika, Manajemen dan Komputer, Vol. 10 No. 1, MEl 2018

eISSN : 2580-3042

pISSN : 1979-0694

6. Data Tahun Ajaran

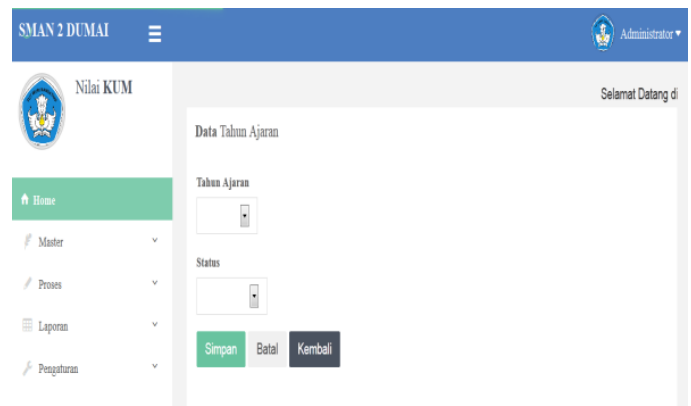

Gambar 11. Data Tahun Ajaran

a. Pada form menu utama pilih sub menu pengaturan, klik tahun ajaran.

b. Input tahun ajaran, status, kemudian klik tombol simpan untuk menyimpan data yang akan disimpan klik tombol batal jika tidak jadi memasukkan data dan kembali jika ingin kembali.

c. Klik tombol administrator dan klik logout apabila ingin keluar dari form input data tahun ajaran.

7. Data Input KUM
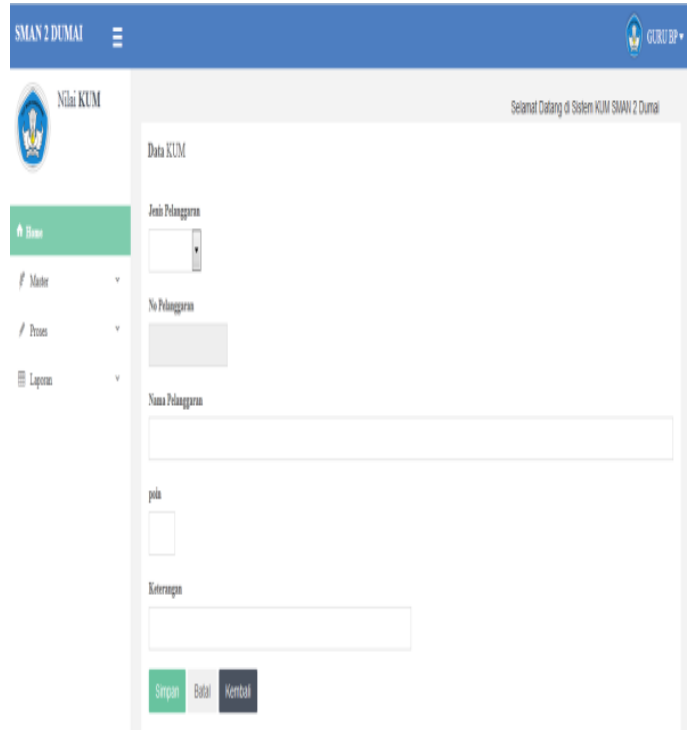

Gambar 12. Data Input KUM

a. Pada form menu utama pilih sub menu master, klik Data KUM.

b. Input kode pelanggaran, huruf, jenis pelanggaran, no pelanggaran, nama pelanggaran, point dan keterangan, klik tombol simpan jika ingin disimpan dan klik tombol batal jika ingin batal, apabila ingin kembali klik tombol klik tombol kembali

c. Klik tombol keluar apabila ingin keluar dari form input data KUM.

8. Data Input Wali Kelas

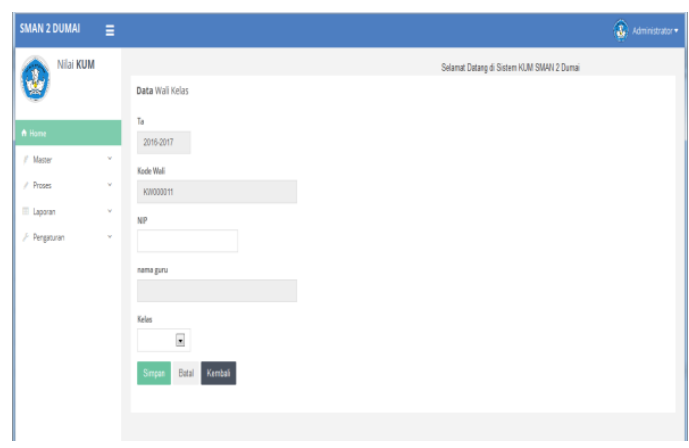

Gambar 13. Data Input Wali Kelas

a. Pada form menu utama klik sub menu proses

b. Kemudian pilih wali kelas

c. Input Ta dan kode wali akan muncul, Input NIP dan nama guru serta kelas. Klik tombol simpan untuk menyimpan data wali kelas dan klik tombol batal jika ingin batal, jika ingik kembali klik tombol kembali

d. Klik tombol administrator kemudian klik tombol logout apabila ingin keluar dari form data wali kelas.

9. Data Transaksi Bagi Kelas

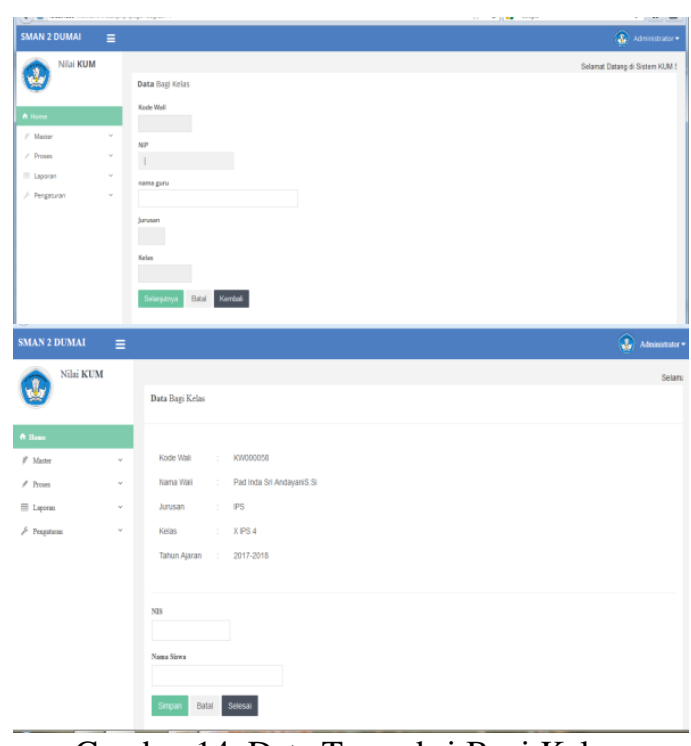

Gambar 14. Data Transaksi Bagi Kelas

a. Pada form menu utama klik sub menu proses.

b. Kemudian pilih Bagi Kelas 
I N F O R M A I I A

Jurnal Informatika, Manajemen dan Komputer, Vol. 10 No. 1, MEl 2018

eISSN : 2580-3042

pISSN : 1979-0694

c. Input NIP akan muncul otomatis keseluruhannya. Klik tombol selanjutnya jika ingin melanjutkan dengan pembagian data kelas siswa dan klik tombol batal jika ingin batal, apabila ingin kembali klik tombol kembali.

d. Setelah data wali dipanggil, maka klik tombol selanjutnya dan akan muncul data kode wali, nama wali, jurusan,kelas,dan tahun ajaran maka inputkan data siswa sesuai pembagian kelas dan simpan sesuai kelas jika ingin batal klik batal jika tidak klik selesai.

e. Klik tombol administrator kemudian klik logout apabila ingin keluar

10. Data Transaksi Perilaku Siswa

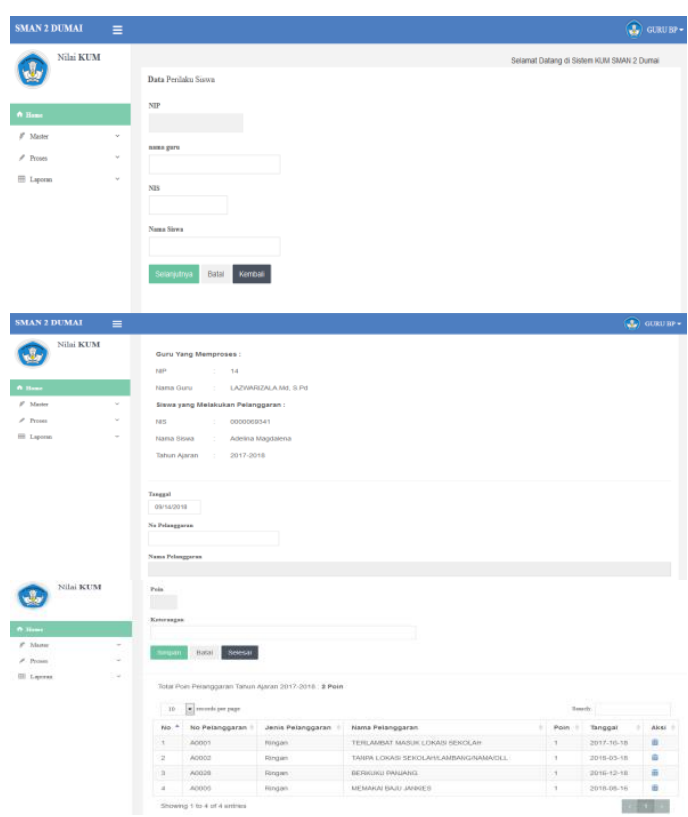

Gambar 15.Data Transaksi Perilaku Siswa

a. Pada form menu utama klik sub menu proses.

b. Kemudian pilih perilaku

c. Input NIP dan NIS maka data akan keluar secara otomatis. Kemudian klik tombol selanjutnya untuk menginput perilaku siswa dan klik tombol batal untuk membatalkan, apabila ingin kembali klik tombol kembali.

d. Setelah mengklik tombol selanjutnya maka akan terlihat guru yang memproses dan siswa yang melakukan kesalahan dan akan kita input data perilaku siswa dengan memanggil data kum yg telah ada lalu disimpan dan data perilaku telah disimpan dan akan terjumlah sesuai data perilaku

kesalahan siswa tersebut dan jika ingin batal klik batal dan jika ingin selesai klik selesai.

e. Klik tombol adminidtrator dan klik logout apabila ingin keluar dari form input data data perilaku siswa.

11.Laporan Data Siswa Keseluruhan

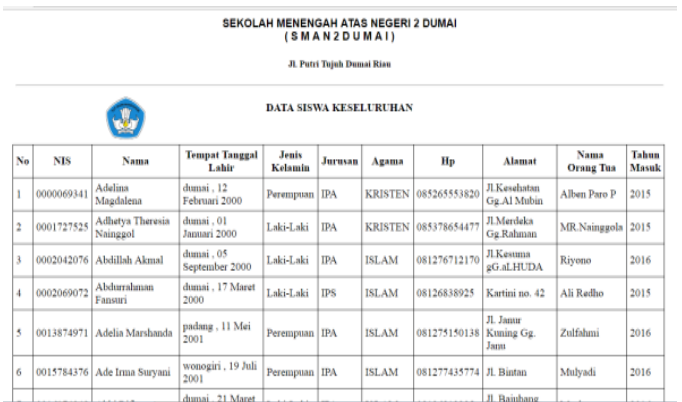

Gambar 16. Laporan Data Siswa Keseluruhan

a. Klik menu laporan untuk melihat konten yang ada didalam laporan

b. Pilih siswa untuk melihat laporan, kemudian klik cetak

c. Pilih jurusan dan tahun untuk melihat laporan data siswa perjurusan dan tahun kemudian klik cetak

d. Maka akan muncul laporan sebagai berikut.

\section{Laporan Data KUM}

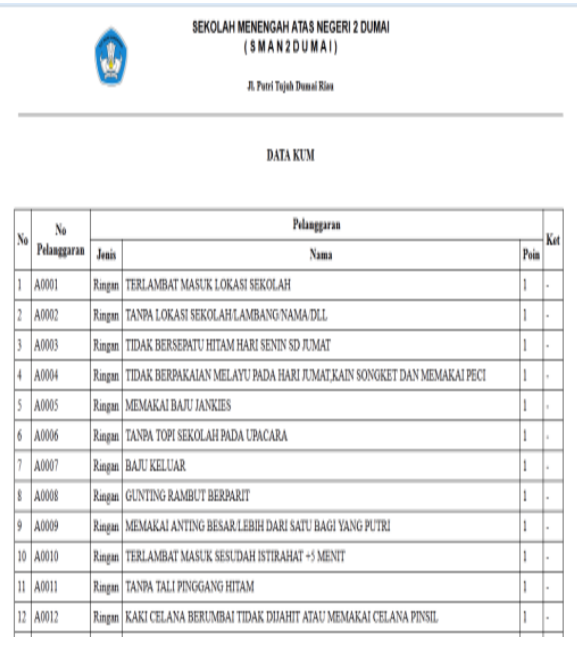

Gambar 17.Laporan Data KUM

a. Klik menu laporan untuk melihat konten yang ada didalam laporan

b. Pilih KUM,untuk melihat laporan, kemudian klik cetak

c. Maka akan muncul laporan sebagai berikut. 
I N F ORM A T I K

Jurnal Informatika, Manajemen dan Komputer, Vol. 10 No. 1, MEl 2018

eISSN : 2580-3042

pISSN : 1979-0694

13.Laporan Data KUM Per Siswa
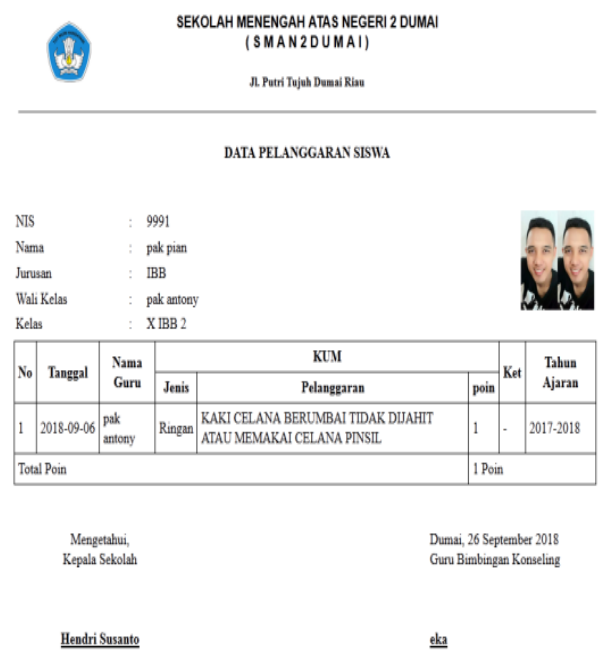

Gambar 18. Laporan Data KUM Per Siswa

a. Klik menu laporan untuk melihat konten yang ada didalam laporan

b. Pilih KUM PerSiswa,untuk melihat laporan, kemudian klik cetak

c. Maka akan muncul laporan sebagai berikut.

14.Laporan Data KUM Per Tahun Ajaran

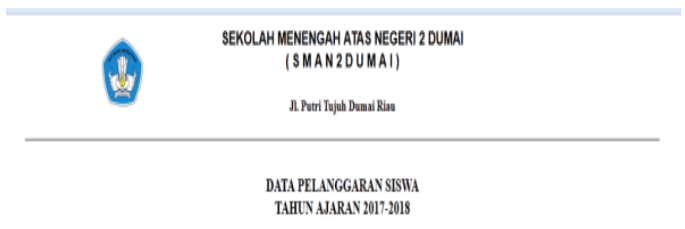

\begin{tabular}{|c|c|c|c|c|c|c|c|}
\hline \multirow{2}{*}{$\mathbf{N}_{0}$} & \multirow{2}{*}{ Tangal } & \multirow{2}{*}{ Sama Guru } & \multirow{2}{*}{ NIS } & \multirow{2}{*}{$\begin{array}{l}\text { Nama } \\
\text { Sisma }\end{array}$} & \multicolumn{3}{|c|}{ KTM } \\
\hline & & & & & Jeais & Pelanggaran & poin \\
\hline 1 & $2018-03.24$ & IssandiSPd & 0014596974 & $\mid$\begin{tabular}{|l} 
Aii \\
Prayogogo
\end{tabular} & Ringan & TIDAK MEVAKAI DASI & 1 \\
\hline 2 & $2018-03 \cdot 24$ & Fitriato & 013884471] & $\mid \begin{array}{l}\text { Adelia } \\
\text { Marstande }\end{array}$ & Ringen & $\begin{array}{l}\text { MEMARAA JAKET YANG BERTULISKAN } \\
\text { PROVOKASITEXAS LANNYADDLINGKUNGAN } \\
\text { SEROLAH }\end{array}$ & 1 \\
\hline & 2018.03 .24 & $\begin{array}{l}\text { LAZTIARZZZLAMd, } \\
\text { SPd }\end{array}$ & 0004883713 & \begin{tabular}{|l|} 
Aqumg \\
Whatyudi
\end{tabular} & Ringan & 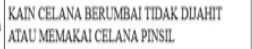 & 1 \\
\hline 4 & $2017-122.24$ & Fintialato & O013874971 & \begin{tabular}{|l|} 
Adelia \\
Marhtanda
\end{tabular} & Ringan & $\begin{array}{l}\text { KAIN CELANA BERLNBAI TIDAK DJAHIT } \\
\text { ATAU MENARAI CELANA PNSSL }\end{array}$ & 1 \\
\hline 15 & $2017 \cdot 09 \cdot 24$ & $\begin{array}{l}\text { LAZWARIZZLAMd, } \\
\text { SPd }\end{array}$ & 0004883713 & \begin{tabular}{|l|} 
Agumg \\
Walyvodi
\end{tabular} & Ringan & TANPA TOP! SEROLAH PADA UPACARA & 1 \\
\hline
\end{tabular}

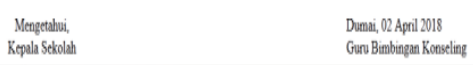

Gambar 19.Laporan Data Per Tahun Ajaran

a. Klik menu laporan untuk melihat konten yang ada didalam laporan

b. Pilih KUM Per TA untuk melihat laporan KUM Per TA

c. Maka akan muncul laporan sebagai berikut.
15.Laporan Data KUM Per Kelas
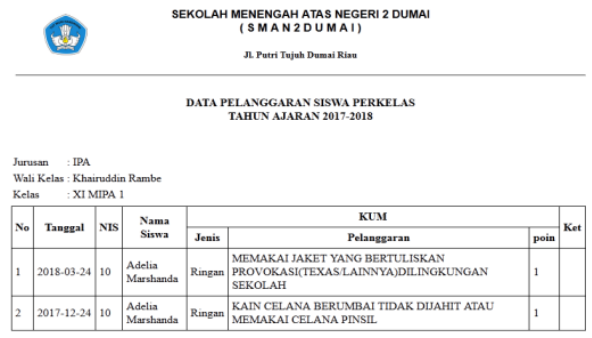

$\underset{\substack{\text { Mengetalui } \\ \text { Kepala secolath }}}{\cos }$

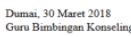

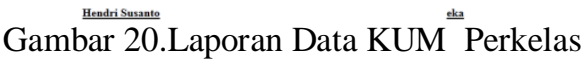

16.Laporan Data KUM Per Minimal

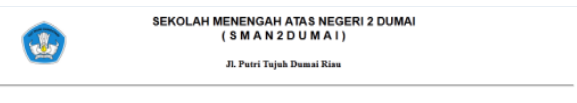

DATA PELANGGARAN SISWA MINMAL 3 POI

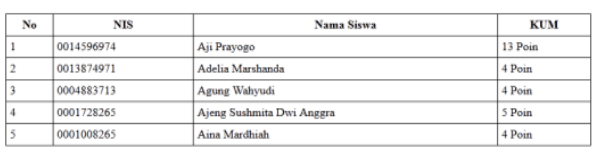

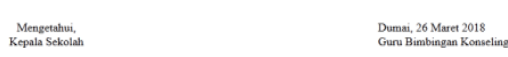

Hendri Susanto

Gambar 21. Laporan Data KUM Per Minimal

a. Klik menu laporan untuk melihat konten yang ada didalam laporan

b. Pilih KUM Minimal,untuk melihat laporan, kemudian klik cetak

c. Maka akan muncul laporan sebagai berikut

17.Laporan Data KUM Per Semester

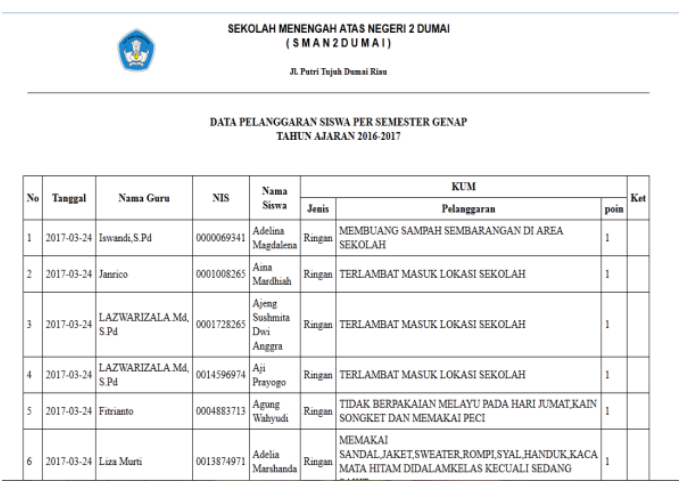

Gambar 22. Laporan Data KUM Per Semester

a. Klik menu laporan untuk melihat konten yang ada didalam laporan

b. Pilih KUM Persemester,untuk melihat laporan, kemudian klik cetak 
IN F O R M A I I A

Jurnal Informatika, Manajemen dan Komputer, Vol. 10 No. 1, MEl 2018

eISSN : 2580-3042

pISSN : 1979-0694

c. Maka akan muncul laporan sebagai berikut

\section{KESIMPULAN}

Berdasarkan analisa dan penelitian yang dilakukan, maka dapat diambil beberapa kesimpulan:

1. Setiap tahun ajaran baru data kum siswa yang lama tidak akan hilang dan tetap otomatis tertambah dengan kum yang baru.

2. Sistem perilaku siswa ini terdapat 3 login yakni admin, guru BP, dan siswa. Setiap login tidak dapat ke login lain oleh sebab itu dipastikan data akan aman.

3. Tidak akan terjadi redudancy data karena telah dibuktikan dengan penyimpanan data yang sama maka akan muncul data sudah ada didalam sistem.

4. Dengan adanya laporan kum minimal, maka mempermudah mencari siswa yang bermasalah dengan nilai kum yang melebihi batas dengan mencari angka di kum minimal maka akan muncul siswa dengan kum yang diinginkan.

\section{REFERENSI}

Ari Prabowo, F., \& Syani, M. (2017). Sistem Informasi Pengolahan Sertifikat Berbasis Web Di Divisi Training Seamolec. 2016) Jmii, 2(1), 73-81.

Dahle, L. K., \& Holman, R. T. (1961). Modified Lodometric Method For Semimicrodetermination Of Lipide Peroxides. Analytical Chemistry, 33(13), 1960-1961.

Https://Doi.Org/10.1021/Ac50154a058

Drs. Hermansyah Sembiring, M. K., \& Nurhayati, S.Kom., M. K. (2012). Sistem Informasi Jumlah Angkatan Kerja Menggunakan Visual Basic Pada Badan Pusat Statistik (Bps) Kabupaten Langkat. Jurnal Kaputama, 5(2), 13-19. Retrieved From

Http://Penelitian.Kaputama.Ac.Id/Images/ Sampledata/File/Jurnal/Jurnal2012/Jurnal 7.Pdf

Kaharu, S., \& Sakina, O. (2015). Perancangan Sistem Informasi Pengolahan Data Akademik Pada Tk Al-Hidayah Lolu. Prototyping Adalah Proses Menghasilkan Sebuah Ide Atau Gagasan Bagi Pembuat Maupun Pemakai Potensial Tentang Cara System Yang Akan Berfungsi Dalam Bentuk Lengkapnya. Ada, 8(1), 73-79. Https://Doi.Org/10.1016/J.Jmmm.2006.10

.792

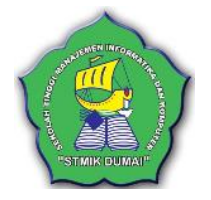

Nia, Kumaladewi, Meinarini Catur Utami, Iskandar, A. (2015). Persediaan Bahan Baku Dan Hasil Produksi Pada Pt, 8(2), $1-13$.

Nurfajrina, D., Suryatiningsih;, \& Siswanto, B. (2016). Aplikasi Pembayaran Bulanan Berbasis Web Dan Sms Gateway Di Smk Negeri 3 Bandung. E-Proceeding of Applied Science, 2(3), 1090-1097.

Rohayati, \& Hj, A. I. (2016). Perancangan Dan Implementasi Sistem Informasi Inventaris Laboratorium. Jurnal Intekna, 16(2), 1519.

Rubiati, N. (2018). Aplikasi Informasi Pelayanan Fitness Pada Golden Fitness Center Dumai Dengan Bahasa Pemrograman Php. Jurnal Informatika, Manajemen Dan Komputer, 10(1), 1-6. Retrieved From Http://Www.Ejournal.Stmikdumai.Ac.Id/I ndex.Php/Path/Article/View/53

Sentosa, Y., Hadiansa, A., \& Rubiati, N. (2017). Aplikasi Pembuatan Kartu Pengenal Siswa Dan Siswi Sekolah Menengah Pertama (Smp) Ykpp Dumai. Jurnal Informatika, Manajemen Dan Komputer, 9(1), 44-48. Retrieved From Http://Www.Ejournal.Stmikdumai.Ac.Id/I ndex.Php/Path/Article/View/63

Web, D. P., \& Kusuma, W. F. (2015). Pengembangan Halaman Web Menggunakan Xml Dalam Perkembangan Web 2.0. Jurnal Teknik Informatika, 6(2), 8 .

Yusuf, R., Kusniyati, H., \& Nuramelia, Y. (2016). Aplikasi Diagnosis Gangguan Kecemasan Menggunakan Metode Forward Chaining Berbasis Web Dengan Php Dan, 9(1), 1-13.

Zakir, A. (2016). Rancang Bangun Responsive Web Layout Dengan Menggunakan Bootstrap Framework. Infotekjar (Jurnal Nasional Informatika Dan Teknologi Jaringan), 1(Issn : 2540-7600), 7-10. Https://Doi.Org/10.30743/Infotekjar.V1i1. 31 